\title{
BLOW FLY (DIPTERA: CALLIPHORIDAE) IN THAILAND: DISTRIBUTION, MORPHOLOGICAL IDENTIFICATION AND MEDICAL IMPORTANCE APPRAISALS
}

\section{NOPHAWAN BUNCHU}

Department of Microbiology and Parasitology and Centre of Excellence in Medical Biotechnology, Faculty of Medical Science, Naresuan University, Muang, Phitsanulok, 65000, Thailand.

${ }^{*}$ Corresponding Author: Email- bunchu_n@hotmail.com

Received: April 03, 2012; Accepted: April 12, 2012

\begin{abstract}
The blow fly is considered to be a medically-important insect worldwide. This review is a compilation of the currently known occurrence of blow fly species in Thailand, the fly's medical importance and its morphological identification in all stages. So far, the 93 blow fly species identified belong to 9 subfamilies, including Subfamily Ameniinae, Calliphoridae, Luciliinae, Phumosiinae, Polleniinae, Bengaliinae, Auchmeromyiinae, Chrysomyinae and Rhiniinae. There are nine species including Chrysomya megacephala, Chrysomya chani, Chrysomya pinguis, Chrysomya bezziana, Achoetandrus rufifacies, Achoetandrus villeneuvi, Ceylonomyia nigripes, Hemipyrellia ligurriens and Lucilia cuprina, which have been documented already as medically important species in Thailand. According to all cited reports, $C$. megacephala is the most abundant species. Documents related to morphological identification of all stages of important blow fly species and their medical importance also are summarized, based upon reports from only Thailand.
\end{abstract}

Keywords- Blow fly, Distribution, Identification, Medical Importance, Thailand

Citation: Nophawan Bunchu (2012) Blow fly (Diptera: Calliphoridae) in Thailand: Distribution, Morphological Identification and Medical Importance Appraisals. International Journal of Parasitology Research, ISSN: 0975-3702 \& E-ISSN: 0975-9182, Volume 4, Issue 1, pp.-57-64.

Copyright: Copyright@2012 Nophawan Bunchu. This is an open-access article distributed under the terms of the Creative Commons Attribution License, which permits unrestricted use, distribution and reproduction in any medium, provided the original author and source are credited.

\section{Introduction}

Thailand is a country located at the centre of the Indochina peninsula in Southeast Asia. It comprises 77 provinces that cover 6 regions by location and its hot and humid climate supports a variety of tropical ecosystems. Unlike the temperate zone, tropical ecosystems provide wider niches for the survival of organisms, which are thus able to support a much larger variety of plant, animal and microbe species. Blow flies form one of many insect groups that are commonly found in the country and their families are classified as follows: Kingdom Metazoa, Phylum Arthropoda, Class Hexapoda, Order Diptera, Suborder Brachycera and Family Calliphoridae. They are characterized typically as being metallic blue, green, purple, or non metallic in color and they vary in size [1]. Blow fly larvae serve as carrion feeders that play an important role in recycling organic materials in the ecosystem. Furthermore, adults have been reported as pollinators of mango flowers in Australia [2] and Taiwan [3]. Over 1,450 blow fly species are distribut- ed over all continents in the world, except Antarctica [1]. Based on citation in this review, the first document related blow fly was reportedly found in 1976 [4] and the first taxonomic key for blow flies (subfamily Calliphoridae) in Thailand was documented by Tumrasvin et al, [5]. The first text book relating to medically-important blow fly species of Thailand was written in the Thai language in 2010 by Associate Professor Dr. Kom Sukontason and Associate Professor Dr. Kabkaew Sukontason [6]. Over the past 36 years, there have been many scientific articles that demonstrate blow fly occurrence in several parts of Thailand as well as the fly's biological aspects and medical importance. Although this information has increased gradually, it is still scattered. Therefore, the objectives of this review were to gather and update all information on blow flies, based upon scientific reports from only Thailand and the experience of this author. This review emphasized on mainly 3 aspects, including (i) the occurrence of blow fly species, (ii) morphological identification of all stages and (iii) their medical im- 
portance. This review may be useful for further researches and able to fulfill the information of blow fly diversity in the country.

\section{Distribution of Blow flies in Thailand}

Briefly, blow flies are classified in the Order Diptera and Family Calliphoridae. They are called "Ma Lang Won Hoa Keaw" (in Thai) and are characterized typically as being metallic blue, green, purple, or non metallic (black, grey, brown or yellow) in color and varied in size (2.5 - $19.0 \mathrm{~mm}$ ) [1]. Females are oviparous, sometimes ovoviviparous and some species breed in decaying animal matter, while others breed in human and animal excrement. The life cycle development for this fly is holometabolous (complete metamorphosis) in four stages: egg, larva, pupa and adult. During the larval stage, the fly passes through 3 different stages or instars by moulting. Morphologically, the egg is small, creamy and banana shaped, while the larva is creamy, muscoid shaped and called a maggot. The pupa is coarctate and barrel shaped. Over 1,450 blow fly species belonging to 133 genera are distributed over all continents worldwide, except Antarctica [1]. In Thailand, there are 93 blow fly species belonging to 9 subfamilies including Subfamily Ameniinae, Calliphoridae, Lucilinae, Phumosiinae, Polleniinae, Bengaliinae, Auchmeromyiinae, Chrysomyinae and Rhiniinae [7], as shown in Table 1.

Table 1- List of blow fly species (Diptera: Calliphoridae) and their distribution in Thailand (by province) from 1975 to 2010 based mainly upon reports by Kurahashi and Bunchu [7], Sucharit and Tumrasvin [9], and partly upon collections made by the author

\begin{tabular}{|c|c|c|c|}
\hline Subfamily & Tribe & Genus and species & Locality \\
\hline \multirow[t]{4}{*}{ AMENIINAE } & Ameniini & $\begin{array}{l}\text { Silbomyia asiatica Cross- } \\
\text { key, } 1965\end{array}$ & Nakhon Nayok \\
\hline & Catapicephalini & $\begin{array}{l}\text { Catapicephala kurahashii } \\
\text { Tumrasvin et Kano, } 1977\end{array}$ & Chiang Mai \\
\hline & & $\begin{array}{l}\text { Catapicephala michikoae } \\
\text { Tumrasvin et Kano, } 1977\end{array}$ & Chumporn \\
\hline & & $\begin{array}{l}\text { Catapicephala sinica } \\
\text { Fan, } 1965\end{array}$ & Chiang Mai, Lampang \\
\hline \multirow[t]{9}{*}{$\begin{array}{l}\text { CALLIPHORI- } \\
\text { NAE }\end{array}$} & Calliphorini & $\begin{array}{l}\text { Melinda abdominalis } \\
\text { (Malloch, 1931) }\end{array}$ & Chiang Mai, Tak \\
\hline & & $\begin{array}{l}\text { Melinda dubia (Malloch, } \\
\text { 1931) }\end{array}$ & Chiang Mai \\
\hline & & $\begin{array}{l}\text { Melinda nigripalpis } \\
\text { Kurahashi et Tumrasavin, } \\
1979\end{array}$ & , Chiang Mai \\
\hline & & $\begin{array}{l}\text { Melinda nuortevae } \\
\text { Kurahashi, } 1970\end{array}$ & $\begin{array}{l}\text { Chiang Mai, Kanchana- } \\
\text { buri }\end{array}$ \\
\hline & & $\begin{array}{l}\text { Melinda scutellata } \\
\text { (Senior-White, 1923) }\end{array}$ & Chiang Mai \\
\hline & & $\begin{array}{l}\text { Calliphora pattoni } \\
\text { Aubertin, } 1931\end{array}$ & Chiang Mai \\
\hline & & $\begin{array}{l}\text { Calliphora vicina } \\
\text { Robineau-Desvoidy, } \\
1830\end{array}$ & Chiang Mai \\
\hline & & $\begin{array}{l}\text { Calliphora vomitoria } \\
\text { (Linnaeus, 1758) }\end{array}$ & Chiang Mai \\
\hline & & $\begin{array}{l}\text { Tainanina } \\
\text { sarcophagoides (Malloch, } \\
\text { 1931) }\end{array}$ & Chiang Mai \\
\hline \multirow[t]{2}{*}{ LUCILIINAE } & & $\begin{array}{l}\text { Lucilia cuprina } \\
(\text { Wiedemann 1830 })^{\mathrm{f}}\end{array}$ & $\begin{array}{l}\text { Bangkok, Chiang Mai, } \\
\text { Phitsanulok, Tak }\end{array}$ \\
\hline & & $\begin{array}{l}\text { Lucilia papuensis } \\
\text { Macquart, } 1842\end{array}$ & $\begin{array}{l}\text { Chiang Mai, Saraburi, } \\
\text { Sa Kaeo, Kanchanaburi }\end{array}$ \\
\hline
\end{tabular}

Table 1 Continue

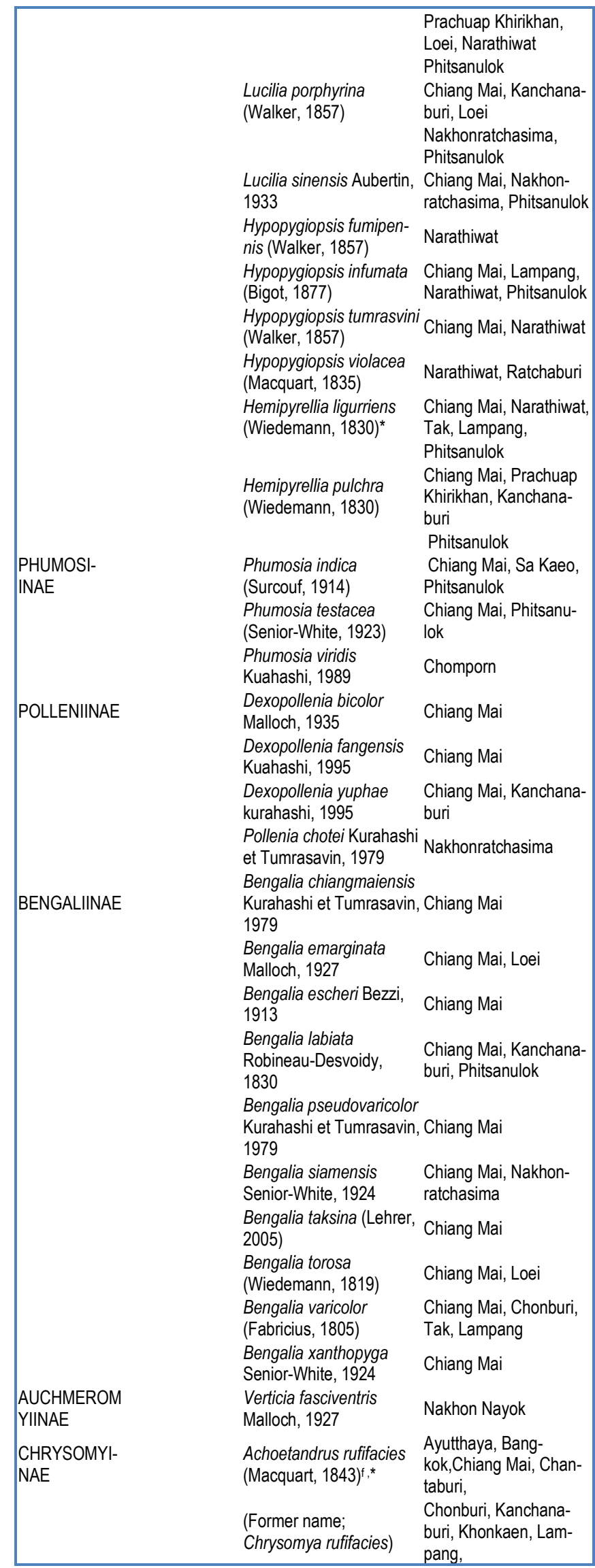


Table 1 Continue

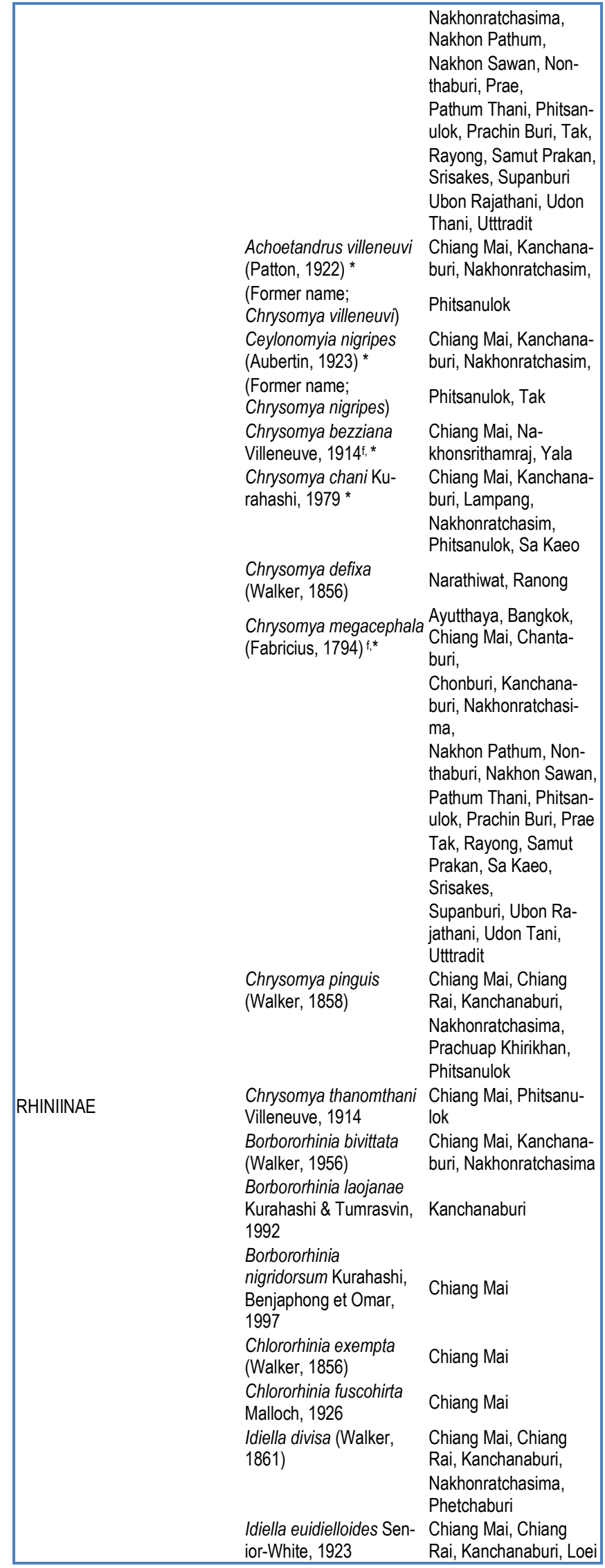

Table 1 Continue

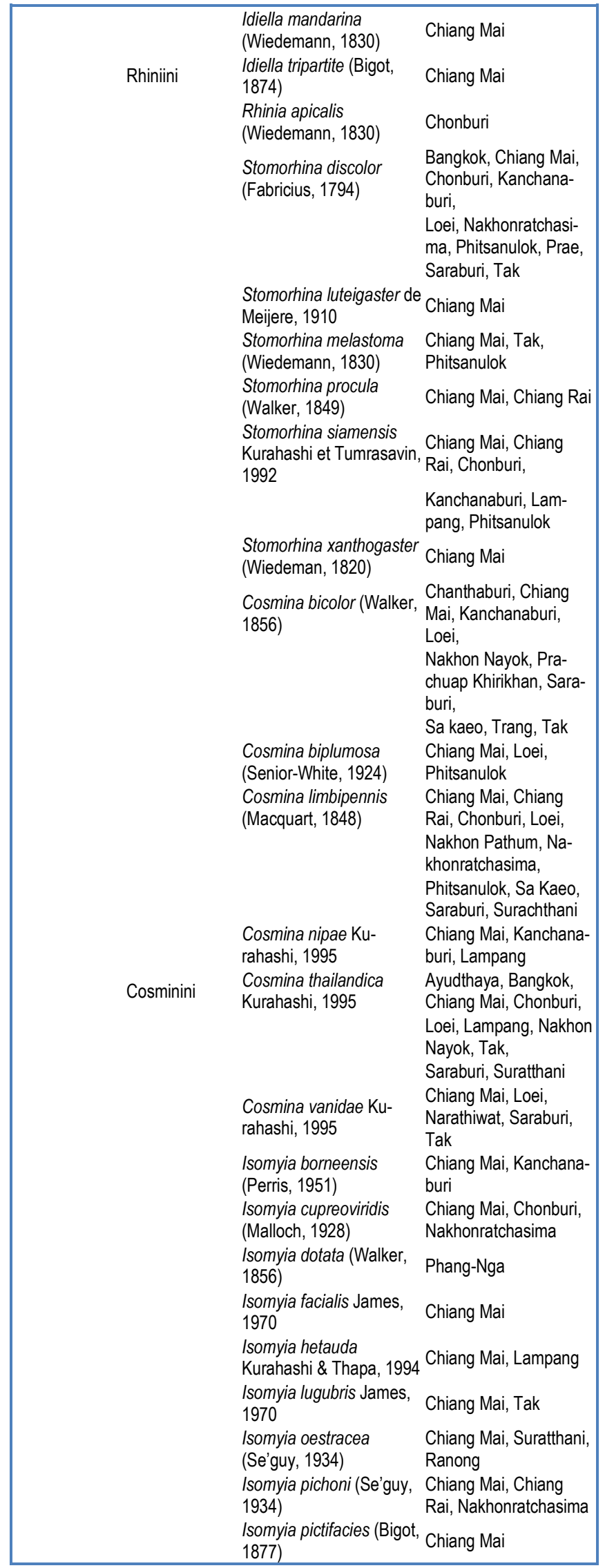


Table 1 Continue

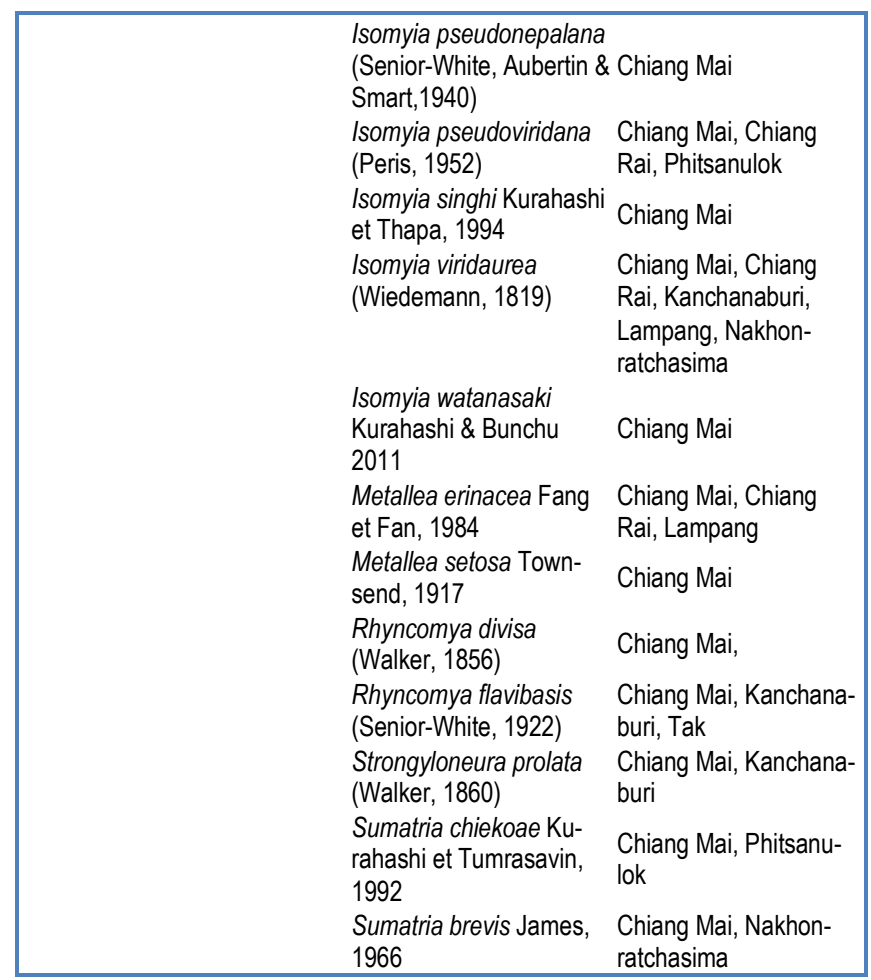

fThese species have been reported as medically important.

*These species have been reported as insects associated with corpses in Thailand.

Most species seem to have Oriental elements $(79 \%)$, followed by Palaearctic (2\%), pantropical or cosmopolitan (2\%) and Afrotropical ones (1\%). About $16 \%$ of species found in Thailand and its adjacent areas are endemic [7].

There are 9 species, including Chrysomya megacephala, Chrysomya chani, Chrysomya pinguis, Chrysomya bezziana, Achoetandrus rufifacies, Achoetandrus villeneuvi, Ceylonomyia nigripes, Hemipyrellia ligurriens and Lucilia cuprina), which are documented as medically important blow fly species. Photographs of these species, except for $C$. bezziana, are shown in Figure 1 and 2. Previous fly surveys conducted in both urban and rural areas in some provinces, such as Ayutthaya, Bangkok, Chiang Mai, Chonburi, Chantaburi, Kanchanaburi, Khonkaen, Nonthaburi, Nakhon Pathum, Nakhon Sawan, Pathum Thani, Phitsanulok, Prachin Buri, Prae, Samut Prakan, Rayong, Srisakes, Supanburi, Ubon Rajathani, Udon Thani and Utttradit, indicated that C. megacephala (Fig. 1A) is the most abundant blow fly species [4,8-12]. Provinces reporting where this blow fly species has been found to occur already are summarized in Fig. 3. Thirty-five provinces out of $77(45.45 \%)$ have reported the occurrence of blow flies scientifically (Table 1 and Figure 3 ). Fig. 3 indicates that the least information on blow fly species in Thailand comes from the northeastern region. Therefore, sample collections and surveys should be carried out there in future to determine the real diversity of blow flies and possibly discover new species or records.
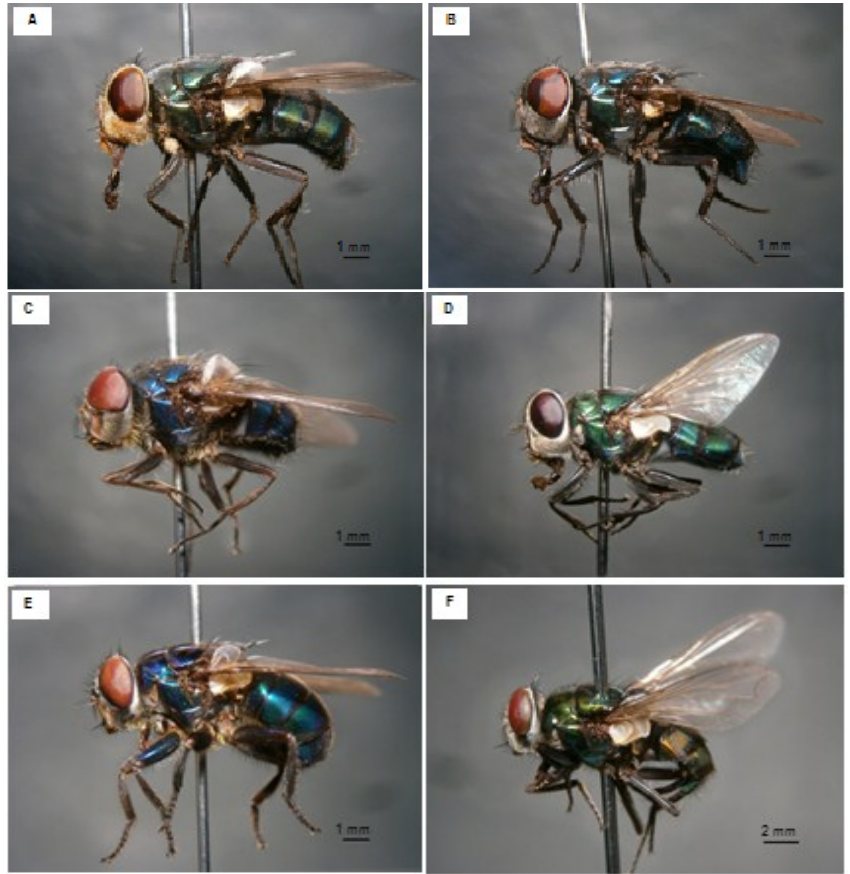

Fig. 1- Lateral views of medically important blow fly species in the Subfamily Chrysomyinae; (A) Chrysomya megacephala, (B) Chrysomya chani, (C) Chrysomya pinguis (D) Achoetandrus rufifacies $(\mathrm{E})$ Achoetandrus villeneuvi and $(\mathrm{F})$ Ceylonomyia nigripes.

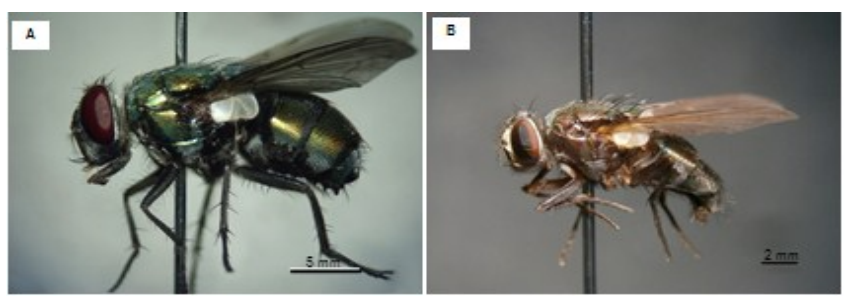

Fig. 2- Lateral views of medically important blow fly species in the Subfamily Lucillinae; (A) Hemipyrellia ligurriens and (B) Lucilia cuprina.

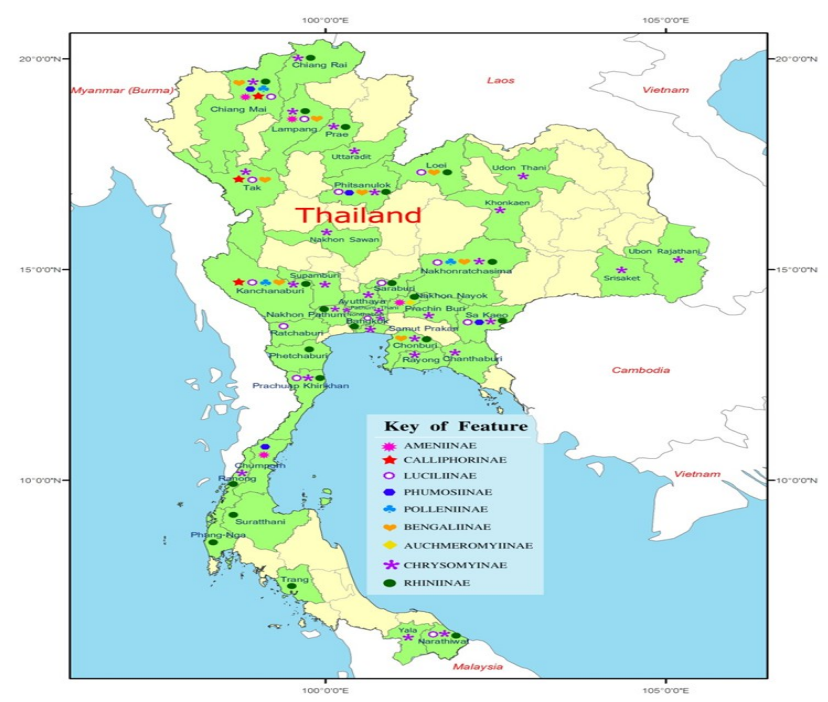

Fig. 3- Distribution of blow flies by subfamily in Thailand; Green areas represent provinces that report blow fly species. 


\section{Morphological identification of blow fly species}

Adult stage- Typically, the adult blow fly is metallic blue, green, purple, or non metallic (black, grey, brown or yellow) in color. Its body size ranges from 2.5 to $19.0 \mathrm{~mm}$ in width. The latest taxonomy key for identifying blow fly species of Thailand has been reported by Kurahashi and Bunchu [7]. Previously, morphologybased identification of the blow fly was determined by following the keys of Tumrasvin et al. [5].

Egg stage- Generally, the blow fly egg is small, creamy and banana shaped. To identify the species, its morphology has been studied by staining with potassium permanganate solution and observing under light microscope (LM) [13] or scanning electron microscope (SEM) [14-15] and transmission electron microscope (TEM) [16]. A key to differentiate the eggs of forensically important flies in Thailand was given by Sukontason et al [16]. The main characteristics for identification include size, median area and chorionic sculpture pattern [16]. Blow fly eggs have been used to determine time of death in the early postmortem interval [17], when precise identification is very important.

Larva stage: The lava is creamy and muscoid shaped. There are 3 instars, i.e., $1^{\text {st }}, 2^{\text {nd }}$ and $3^{\text {rd }}$ instars and a number of spiracular slits in the posterior spiracle can be used to differentiate between them. The main characteristics for identification include body appearance (with or without tubercle), which includes cephalopharyngeal skeleton (size and morphology), spine between the 1 st and $2^{\text {nd }}$ segments, peritreme (complete or incomplete), posterior spiracle (size, morphology and color) and number of papillae on the anterior spiracle. A simple technique for observing these organs is the clearing technique using potassium hydroxide [18-20] and methyl salicylate [21]. Analysis of cuticular muscle attachment sites is reported currently as a new method for species determination in third instar larvae of saprophagous blow flies [22]. Medically important blow fly larvae of Thailand (C. megacephala, A. rufifacies, $A$. villeneuvi, $C$. nigripes, $L$. cuprina, $H$. ligurriens) have been studied by observing under SEM [23-28]. The identification key for third instar of some important blow fly species in Thailand (C. megacephala, A. rufifacies, C. nigripes and L. cuprina) was reported previously by Sukontason et al., [20].

Pupa stage: The pupa is mahogany brown to dark brown in color and coarctate and barrel shaped. Morphology of puparium has been studied widely under LM [29] and SEM [30-35]. A simply key to identify the puparium of some blow fly species of Thailand was summarized by Sukontason et al. [29]. The main characteristics for identification include body appearance (with or without tubercle), such as the $3^{\text {rd }}$ thoracic segment to $1^{\text {st }}$ abdominal segment, distance between right and left posterior spiracles, number of bubble membranes and papillae on the anterior spiracle [29-35].

\section{Medically-important aspects of the blow fly: Thailand apprais-} al

The blow fly is considered to be a medically-important insect worldwide, with both positive and negative impact. Its negative impact plays an important role in being a nuisance and mechanical carrier of pathogens and causing myiasis [e.g. 36-45]. On the other hand, it is beneficial when applied in debridement therapy [46] and forensic entomology [47]. The details of all medicallyimportant aspects are reviewed below.
Myiasis- Myiasis is a disease known to be caused by invasion of dipterous larvae [48]. It can be classified according to its localization, or tissue or organ involved, maggot feeding behavior and entomology [49]. According to localization of the embedded larvae, myiasis can be categorized as cutaneous, subcutaneous or cavitary. The most widely used classification divides myiasis into 3 types, according to the causative agent and pathogenic behavior: (i) primary (or obligatory), (ii) facultative and (iii) accidental. Many species of Diptera may cause larval infestation or infection in humans [49]. Blow fly maggots have been recognized as myiasis producers worldwide, in several countries such as Brazil [50-51], India [44], Thailand [41, 52-53] and Sri Lanka [54]. Human myiasis in Thailand is an uncommon parasitic infestation. The only myiasis producing species reported in this country include $C$. bezziana [52 -53], C. megacephala [41] and $A$. rufifacies [41]. All human myiasis cases caused by $C$. bezziana have been found in $\mathrm{Na}$ khonsrithamraj and Yala provinces, southern Thailand [52-53]. C. bezziana, which is known widely as the old world screwworm, has been recognized as a cause of cavitary myiasis in Africa, Asia and Indonesia [55] and an obligatory-myiasis producer. On the other hand, myiasis cases have been caused by $C$. megacephala and $A$. rufifacies, as found in Chiang Mai province, northern Thailand [41]. C. megacephala and $A$. rufifacies have been incriminated as facultative-myiasis producers. To force the larva to leave its cavity, asphyxiation by occlusion of the breathing hole, using an occlusive agent (e.g., liquid paraffin, petrolatum, wax, resins, glue, adhesive tape, nail polish, chewing gum, or strips of pork fat), is a possible therapeutic approach for cutaneous or subcutaneous myiasis $[49,56]$. Alternatively, the larva can be removed surgically by using forceps after simple incision of the lesion [55], if there is a high larval load or when requested by the patient [49]. For cavitary myiasis, ether, chloroform and rapid passes of liquid nitrogen can be used topically to facilitate the removal of superficial maggots. Topical or oral invermectin has been recommended to treat lesions that are located in difficult-to-reach sites [57-58].

Mechanical carrier- Blow flies play an important role in mechanical transmission of several pathogens, including bacteria, fungi, cysts of protozoa and eggs of helminthes [38-39, 45, 59-61]. The adhesive device or the pulvilli, pad-like structure between the tarsal claws of the legs is an important organ that supports the blow fly's role as a mechanical carrier [62]. All related studies of blow flies in Thailand have focused only on the transmission potential of $C$. megacephala because it is the most predominant species and considered to be eusynanthropic [4,8-12]. Furthermore, C. megacephala consumes both contaminated and noncontaminated food and has great flight activity and dispersal as well as constantly alternating between feces and food in its feeding behavior [59].

Study on the mechanical carrier of bacterial enteric pathogens by C. megacephala in Chiang Mai province, northern Thailand showed a total of 39 bacterial species, with 8 groups isolated and three species previously reported as bacterial enteric pathogens that cause diarrheal diseases, including Aeromonas hydrophila, Edwardsiella tarda and Vibrio cholerae non-01 [39]. Nonfermentative gram-negative bacilli and coagulase-negative staphylococci were isolated from C. megacephala in urban areas of Chiang Mai [60] and this blow fly species was more potentially 
dangerous for public health than the house fly, Musca domestica [61]. Srivoramas et al., [45] recently confirmed that $C$. megacephala has the ability to function as a mechanical carrier of fungal spores and is able to transmit fungi to humans in Ubon Ratchathani province, northeastern Thailand.

Maggot debridement therapy (Maggot therapy)- Successful maggot therapy was first reported in 1931 [63], but not all species of flies are safe and effective as medicinal maggots. The fly used most often for this purpose is the blow fly; and the species most commonly utilized is Lucilia (Phaenicia) sericata or green bottle fly [64]. This blow fly has not been found in Thailand [7] and is more specific to Holarctic areas such as Australia, America and Canada [65]. L. cuprina is the only species found in Thailand that has been reported from several countries as a medicinal maggot [6668]. The sterile maggots of $L$. cuprina have been used to debride necrotic tissue from wound surfaces in Egypt [66] and Malaysia [67-68]. Up until now, no report has related to the use of this maggot for debridement therapy in Thailand.

Forensic entomology- Forensic entomology is a wide field that encompasses law with all interactions of insects and other arthropods. The main applications include (a) determination of time (Postmortem Interval: PMI) and location of human death, (b) determination of circumstances surrounding death, (c) evidence of postmortem corpse relocation and (d) association of suspects with a death scene [69]. Studies in forensic entomology in Thailand have focused consistently on two main areas including basic research and case studies. Basic research has focused on biological information, which serves to support the application of insect evidence in forensic investigations in Thailand. Studies on blow fly biology and morphology have emphasized consistently that this insect is the first to colonize a carcass, often within minutes of exposure $[47,70]$. Furthermore, a study revealed that insects associated with pig (Sus scrofa) carcasses in Thailand were found primarily in Phitsanulok province [71]. C. megacephala and $A$. rufifacies, are considered the most forensically-important blow fly species in the country [71-75]. Accordingly, the first documented case report in Thailand was published by Sukontason et al. [72]. Between 2000 and 2006, 30 cases involved the transfer of cadavers to the Department of Forensic Medicine, Faculty of Medicine, Chiang Mai University where the collection of arthropod evidence comprised C. megacephala, A. rufifacies, A. villeneuvi, C. nigripes, C. bezziana, C. chani, L. cuprina, H. ligurriens and two unknown species [73]. Similar species have been found to associate with human corpses in Malaysia [76-77]. All of the fly specimens were useful for estimating PMl and predicting cause of death by colonizing wounds [72-74]. Specimens of $A$. rufifacies were used to estimate the PMI in a floating corpse in Lampang province, northern Thailand [73]; while C. megacephala helped to evaluate the PMI of a corpse in Khonkaen province, northeastern Thailand [75].

\section{Conclusion}

Currently, there are 93 blow fly species recorded in 35 provinces of Thailand, with the possibility of more species being reported from other provinces. Therefore, continuous site-specific sample collections and surveys should be carried out in the future to de- termine the actual diversity of the blow fly species and possibly find new species or new records. This information is very important for the database on blow fly diversity and further application in medical and forensic entomology researches.

\section{Acknowledgement}

This study was supported mainly by a grant from the Faculty of Medical Science, Naresuan University and a grant from the Thailand Research Fund (MRG5280194). I would like to thank Hiromu Kurahashi (Department of Medical Entomology, National Institute of Infectious Disease, Japan) who contributed to this study of blow flies. Thanks are extended to Polprecha Chidburee (Faculty of Agriculture Natural Resources and Environment, Naresuan University, Thailand) and Sangob Sanit (Department of Parasitology, Faculty of Medicine, Chiang Mai University, Thailand) for the geographic maps and photographs in this review. Kom Sukontason and Kabkaeaw L. Sukontason (Department of Parasitology, Faculty of Medicine,Chiang Mai University, Thailand) also are acknowledged for their valuable suggestions. I also thank the Centre of Excellence in Medical Biotechnology, Faculty of Medical Science, Naresuan University and the Division of Research Administration, Naresuan University, for supporting and defraying the publication cost.

\section{References}

[1] Verves Y.G. (2005) Int. J. Dipterol. Res., 16, 233-310.

[2] Anderson D.L., Sedgley M. and Short J.R.T. (1982) Aust. J. Agric. Res., 33, 541-548.

[3] Hu T.C., Len C.H. and Lee B.S. (1995) Chin. J. Entomol., 15, 103-111.

[4] Sucharit S., Tumrasvin W. and Vutikes S. (1976) Southeast Asian J. Trop. Med. Public Health., 7, 85-90.

[5] Tumrasvin W., Kurahashi H. and Kano R. (1979) Bull. Tokyo Med. Dent. Univ., 26, 243-72.

[6] Sukontason K. and Sukontason K.L. (2010) Blow flies of medical importance in Thailand.

[7] Kurahashi H. and Bunchu N. (2011) Jpn. J. syst. Ent .,1, 237278.

[8] Tumrasvin W., Sucharit S. and Kano R. (1978) Bull. Tokyo Med. Dent. Univ., 25, 77-81.

[9] Sucharit S. and Tumrasvin W. (1981) Jpn. J. Sanit. Zool., 32, 281-285.

[10]Boonchu N., Piangjai S., Sukontason K.L. and Sukontason K. (2003) Southeast Asian J. Trop. Med. Public Health., 34, 630633.

[11]Lertthamnongtham S., Sukontason K.L., Sukontason K., Piangjai S., Choochote W., Vogtsberger R.C. and Olson J.K. (2003) Ann. Trop. Med. Parasitol., 97, 87-91.

[12]Ngoen-klan R., Moophayak K., Klong-klaew T., Irvine K.N. Sukontason K.L., Prangkio C., Somboon P. and Sukontason K. (2010) Parasitol. Res., 109, 1279-1292.

[13]Sukontason K., Sukontasona K.L., Piangjai S., Bunchu N., Kurahashi H., Hope M. and Olson J.K. (2004) Micron, 35, 391 $-395$.

[14]Erzinclioglu Y.Z. (1989) Med. Vet. Entomol., 3:, 281-285. 
[15]Sukontason K., Sukontason K.L., Piangjai S., Choochote W., Boonchu N., Chaiwong T. and Kurahashi H. (2004) Biol. Res., 37, 483-487.

[16]Sukontason K.L., Bunchu N., Chaiwong T., Kuntalue B. and Sukontason K. (2007) J. Insect. Sci., 7-9.

[17]Anderson G.S. (2004) Int. J. Legal. Med., 118, 240-241.

[18]Sukontason K., Methanitikorn R., Sukontason K.L., Piangjai S. and Olson J.K. (2004) J. Vector. Ecol., 29, 192-195.

[19]Sukontason K., Sukontason K.L., Ngern-Klun R., Sripakdee D. and Piangjai S. (2004) Ann. Entomol. Soc Am., 97, 10691075.

[20]Sukontason K., Sribanditmongkol P., Ngoen-klan R., Klongklaew T., Moophayak K. and Sukontason K.L. (2010) Parasitol. Res., 106, 641-646.

[21]Niederegger S., Wartenberg N., Spiess R. and Mall G. (2011) Forensic. Sci. Int., 206, e96-8.

[22]Niederegger S., Spieß R. (2011) Parasitol. Res.

[23]Sukontason K., Sukontason K.L., Piangjai S., Chaiwong T., Boonchu N. and Kurahashi H. (2003) J. Med. Entomol., 40, 983-4.

[24]Sukontason K.L., Sukontason K., Lertthamnongtham S., Kuntalue B., Thijuk N., Vogtsberger R.C. and Olson J.K. (2003) J. Med. Entomol., 40, 259-267.

[25]Sukontason K.L., Sukontason K., Piangjai S., Boonchu N., Chaiwong T., Vogtsberger R.C., Kuntalue B., Thijuk N. and Olson J.K. (2003) J. Vector. Ecol., 28, 47-52.

[26]Sukontason K., Sukontason K.L., Piangjai S., Narongchai P., Samai W., Boonchu N., Sripakdee D., Ngern-Klun R. and Siriwattanarungsee S. (2005) Forensic Sci. Int., 154, 195-199.

[27]Sukontason K.L., Piangjai S., Boonsriwong W., Bunchu N. Ngern-klun R., Vogtsberger R.C. and Sukontason K. (2006) Parasitol. Res., 99, 669-674.

[28]Sukontason K., Sribanditmongkol P., Ngoen-klan R., Klongklaew T., Moophayak K. and Sukontason K.L. (2010) Parasitol. Res., 106, 641-646.

[29]Sukontason K.L., Ngern-Klun R., Sripakdee D. and Sukontason K. (2007) Parasitol. Res., 101, 1407-1416.

[30]Siriwattanarungsee S., Sukontason KL., Kuntalue B., Piangjai S., Olson J.K. and Sukontason K. (2005) Parasitol. Res., 96, 166-170.

[31]Sukontason K.L., Piangjai S., Boonsriwong W., Bunchu N., Ngern-klun R., Vogtsberger R.C. and Sukontason K. (2006) Parasitol. Res., 99, 69-74.

[32] Sukontason K.L., Kanchai C., Piangjai S., Boonsriwong W., Bunchu N., Sripakdee D., Chaiwong T., Kuntalue B., Siriwattanarungsee S. and Sukontason K. (2006) Forensic. Sci. Int., $161,15-19$

[33]Sukontason K.L., Narongchai P., Kanchai C., Vichairat K., Piangjai S., Boonsriwong W., Bunchu N., Sripakdee D., Chaiwong T., Kuntalue B., Siriwattanarungsee S. and Sukontason K. (2006) Forensic. Sci .Int., 164, 230-234.

[34]Sukontason K.L., Piangjai S., Bunchu N., Chaiwong T., Sripakdee D., Boonsriwong W., Vogtsberger R.C. and Sukontason K. (2006) Parasitol. Res., 98, 482-487.

[35]Sukontason K.L., Sribanditmongkol P., Chaiwong T., Vogtsberger R.C., Piangjai S. and Sukontason K. (2008) Parasitol. Res. 2008, 103, 877-887.
[36]Greenberg B. (1973) Flies and disease. Biological and disease transmission.

[37]Echeverria P., Harrison B.A., Tirapat C. and McFarland A. (1983) Appl. Environ. Microbiol., 46, 32-36.

[38]Monzon R.B., Sanchez A.R., Tadiaman B.M., Najos O.A., Valencia E.G., de Rueda R.R. and Ventura J.V. (1991) Southeast Asian J. Trop. Med. Public Health., 22, 222-228.

[39]Sukontason K., Bunchoo M., Khantawa B., Piangjai S., Sukontason K., Methanitikorn R. and Rongsriyam Y. (2000) Southeast Asian J. Trop. Med. Public Health., 31, 157-161.

[40]Sulaiman S., Othman M.Z. and Aziz A.H. (2000) J. Vector. Ecol., 25, 90-93.

[41]Sukontason K.L., Narongchai P., Sripakdee D., Boonchu N. Chaiwong T., Ngern-Klun R., Piangjai S. and Sukontason K. (2005) J. Med. Entomol., 42, 702-704.

[42] Getachew S., Gebre-Michael T., Erko B., Balkew M. and Medhin G. (2007) Acta. Trop., 103, 186-194.

[43]Fetene T. and Worku N. (2009) Trans. Roy. Soc .Trop .Med. Hyg., 103, 187-191.

[44]Ghosh T., Nayek K., Ghosh N. and Ghosh M.K. (2011) Indian Pediatr., 48, 321-323.

[45]Srivoramas T., Chaiwong T. and Sanford R.M. (2012) Int. J. Parasitol. Res., 4, 53-56.

[46]Davydov L. (2011) J. Pharm. Pract., 24, 89-93.

[47]Greenberg B. (1991) J. Med. Entomol., 28, 565-575.

[48]Triplehorn C.A. and Johnson N.F. (2004) Borror and Delong's introduction to the study of insects.

[49]Cestari T.F., Pessato S. and Ramos-e-Silva M. (2007) Clin. Dermatol., 25, 158-164.

[50]Fernandes L.F., Pimenta F.C. and Fernandes F.F. (2009) J. Parasitol., 95, 32-38.

[51]Ferraz A.C., Proença B., Gadelha B.Q., Faria L.M., Barbalho M.G., Aguiar-Coelho V.M. and Lessa C.S. (2010) J. Med. Entomol., 47, 487-490.

[52]Papasarathorn T. and Piyarasana S. (1962) J. Med. Ass. Thai., 45, 47-52.

[53]Papasarathorn T., Chularerk P., Limcharoen C. and Rojanapremsook J. (1967) J. Med. Ass. Thai., 50, 761-765.

[54]Kumarasinghe S.P., Karunaweera N.D. and Ihalamulla R.L. (2000) Int. J. Dermatol., 39, 689-694.

[55]Diaz J.H. (2006) J. Travel. Med., 13, 100-111.

[56]Choontanom R., Thanos S., Busse H. and Stupp T. (2008) J. Pediatr., 153, 297.

[57]Victoria J., Trujillo R. and Barreto M. (1999) Int. J. Dermatol., 38, 142-144.

[58]Osorio J., Moncada L., Molano A., Valderrama S., Gualtero S. and Franco-Paredes C. (2006) Clin. Infec. Dis., 43, e57-9.

[59]Greenberg B. (1971) Ecology, Classification and Biotic Association, Flies and disease.

[60]Smith K.G.V. (1973) Insects and other arthropods of medical importance.

[61]Sukontason K.L., Bunchoo M., Khantawa B., Piangjai S., Rongsriyam Y. and Sukontason K. (2007) Southeast Asian J. Trop. Med. Public Health., 38, 38-44.

[62]Sukontason K.L., Bunchu N., Methanitikorn R., Chaiwong T., Kuntalue B. and Sukontason K. (2006) Parasitol. Res., 98, 477-481.

[63]Baer W.S. (1931) J. Bone. Joint. Surg., 13, 438-475. 
[64]Chan D.C.W., Fong D.H.F., Leung J.Y.Y., Patil N.G. and Leung G.K.K. (2007) Hong Kong Med. J., 13, 382-386.

[65]Rueda L.C., Ortega L.G., Segura N.A., Acero V.M. and Bello F. (2010) Biol. Res., 43, 197-203.

[66]Tantawi T.I., Williams K.A. and Villet M.H. (2010) J. Med. Entomol., 47, 491-494.

[67]Paul A.G., Ahmad N.W., Lee H.L., Ariff A.M., Saranum M., Naicker A.S. and Osman Z. (2009) Int. Wound J., 6, 39-46.

[68]Yeong Y.S., Nazni W.A., Santana R.L., Mohd Noor I., Lee H.L. and Mohd Sofian A. (2009) Trop. Biomed. 28, 325-332.

[69]Hall N.H. (1990) Medicocriminal Entomology, Entomology \& death: A procedural guide.

[70]Catt E.P. (1992) J. Agric. Entomol., 9, 245-255.

[71]Apichat V., Wilawan P., Udomsak T., Chanasorn P. and Saengchai N. (2007) Trop. Biomed., 24, 1-5.

[72]Sukontason K., Sukontason K., Vichairat K., Piangjai S., Lertthamnongtham S., Vogtsberger R.C. and Olson J.K. (2001) J Med. Entomol., 38, 746-748.

[73]Sukontason K.L., Narongchai P., Sukontason K., Methanitikorn R. and Piangjai S. (2005) J. Med. Assoc. Thai., 88, 1458-1461.

[74]Sukontason K., Narongchai P., Kanchai C., Vichairat K., Sribanditmongkol P., Bhoopat T., Kurahashi H., Chockjamsai M., Piangjai S., Bunchu N., Vongvanich S., Samai W., Chaiwong T., Methanitikorn R., Ngern-klun R., Sripakdee D., Boonsriwong W., Siriwattanarungsee S., Srimuangwong C., Hanterdsith B., Chaiwan K., Srisuwan C., Upakut S., Moopayak K., Vogtsberger R.C., Olson J.K. and Sukontason K.L. (2007) Parasitol. Res., 101, 1417-1423.

[75]Sritavanich N., Jamjanya T., Hanboonsong Y. and Jamsuwan A. (2007) KKU Res. J., 7, 1-4.

[76]Lee H.L., Krishnasamy M., Abdullah A.G. and Jeffery J. (2004) Trop Biomed, 21, 69-75.

[77]Syamsa R.A., Ahmad F.M., Marwi M.A., Zuha R.M. and Omar B. (2010) Med. J. Malaysia., 65, 192-195. 